\title{
PELATIHAN MANAJEMEN USAHA DAN PENGELOLAAN KEUANGAN UKM BAGI TENAGA KERJA INDONESIA (TKI) PURNA DI SUKABUMI JAWA BARAT
}

\author{
Oleh: \\ Ari Saptono ${ }^{1}$ ), Rr. Ponco Dewi ${ }^{2}$ ) Suparno ${ }^{3}$ ) \\ Fakultas Ekonomi Universitas Negeri Jakarta
}

\begin{abstract}
ABSTRAK
Pelatihan manajemen usaha dan pengelolaan keuangan UKM sebagai bentuk pembinaan usaha mandiri bagi TKI purna dilaksanakan di ruang pertemuan Kelurahan Cibolang pada tanggal 20 agustus 2016. Diikuti oleh 22 peserta para TKI purna di wilayah Sukabumi, Jawa Barat.

Hasil Pengabdian Masyarakat ini adalah pelatihan manajemen usaha dan pengelolaan keuangan bagi UKM sangat bermanfaat dalam memberikan motivasi dan memanfaatkan peluang usaha serta informasi dalam pengelolaan keuangan UKM. Program pengabdian Masyarakat ini sebagai bentuk pelaksanaan Tri Darma Perguruan Tinggi bagi UNJ dan menyambung tali silaturami Antara Perguruan Tinggi dengan Masyarakat.
\end{abstract}

Kata Kunci : Manajemen Usaha, Pengelolaan Keuangan UKM, TKI Purna

\section{PENDAHULUAN}

A. ANALISIS SITUASI

Kondisi ekonomi yang tidak memberikan akses terhadap pendapatan membuat para TKI keluar negeri. Wilayah pedesaan yang masih menggantungkan pada usaha tradisionaldan pertanian. Para pemuda yang tidak tertarik terhadap pekerjaan pada sector tersebut terdorong mencari akses pendapatan yang lebih baik dengan menjadi TKI keluar negeri. Kisah TKI sukses membangun daerah asal dan menampakkan diri dengan modernisasi menjadi faktor pendorong kuat bagi kalangan muda untuk menelusuri jejak pahlawan devisa.

Wilayah asal sebagai tanah para TKI tumbuh dan berkembang sangat mereka banggakan. Hal tersebut menjadi rutinitas yang sering kita lihat para TKI Mudik. Para pahlawan devisa tersebut berbagi pengalaman dan melepas kerinduan pada sanak keluarga. Bervariasi lama kerja mereka keluar negeri dengan suka dan dukanya. Setelah masa berkumpul dengan keluarga lewat maka mereka segera meninggalkan tanah air serta keluarga tercinta untuk merantau ke negeri jiran kembali.

Pertanyaan besar untuk para TKI kita adalah apakah mereka akan selamanya menjadi TKI keluar negeri. Seperti banyak kita temui berita di media bahwa selain mendapatkan akses pendapatan dan kesuksesan, banyak TKI yang bermasalah. Ada yang meninggalkan keluarganya yang masih kecil didesa hingga perlakuan majikan yang tidak sesuai dengan harapan. Hal tersebut menjadi masalah terselubung bagi para TKI yang sangat besar untuk berpikir dua kali lipat ketika kembali keluar negeri.

Membangun wirausaha dan mengembangkan ekonomi keluarga. Apabila hal tersebut dapat mereka lakukan maka keluar negeri dengan susah payah akan berganti menjadi majikan dinegeri sendiri dan ketenangan bersama keluarga. Walaupun modal yang diperoleh telah cukup, tanpa dorongan keluarga dan keterampilan usaha yang cukup tidak akan mendorong para TKi untuk tidak kembali merantau. Keterampilan membangun usaha dengan melihat potensi, peluang, modal, manajemen dan prospek yang baik akan sangat dibutuhkan bagi para TKI di tanah air. Apabila didukung dengan perencanaan keuangan yang kuat dan keterampilan membuat laporan keuangan bagi UKM maka akses permodalan bagi mereka juga bukan menjadi masalah lagi.

Perjuangan dalam berwirausaha saat ini memang bukan masalah mudah. Kondisi perekonomian dan bisnis yang tidak menentu membuat jumlah PHK semakin tinggi. Kendala 
besar bagi mereka untuk merintis ekonomi berwirausaha semakin tinggi dengan rendahnya daya beli karena pendapatan yang kecil pada sektor konsumsi. Tetapi apabila kita cermati dengan baik dan rasa optimis, maka semua kejadian PHK, hambatan membangun usaha, akan menjadi pemicu besar dalam membangun usaha sendiri.

Keinginan untuk merintis suatu jenis usaha umumnya terkendala oleh keterbatasan modal dan ketiadaan kepemilikan aset yang dapat dijadikan agunan. Tawaran kredit UMKM dari pengusaha dan perbankan sulit diakses oleh kaum miskin, karena keterbatasan kemampuan dan asset yang dimiliki. Pemerintah dalam hal ini dinas sosial berusaha menemukan pola yang efektif agar kaum miskin dapat memperoleh akses modal usaha tanpa agunan dengan tetap mendorong tanggungjawab bersama melalui pola terpadu Kelompok Usaha Bersama (KUBE) dan Lembaga Keuangan Mikro (LKM). Tetapi bukan berarti semua kegiatan tersebut tanpa adanya supervisi usaha. Mereka harus membuat perencanaan usaha, pelaporan perkembangan usaha serta pelaporan keuangan yang baik.

Dengan berbagai permasalahan dan peluang bagi para TKI diatas, maka keterampilan yang paling mendasar sebagai bekal yang harus diperoleh adalah kemampuan menajemen usaha dan pengelolaan keuangan. Dengan kemampuan tersebut akan dapat melihat suatu potensi dan optimalisasi suatu sumber daya. Dimanapun para TKI tersebut berada akan menjadi keterampilan melihat peluang dan mengembangkan, yang pada akhirnya dengan berwirausaha akan menjadi tuan dinegeri sendiri.

Berdasarkan data BNP2TKI (2015) juga diketahui bahwa di Jawa Barat terdapat sembilan kabupaten/Kota yang menjadi daerah pemasok TKI terbanyak. Kesembilan daerah itu yakni Kabupaten Indramayu, Cirebon, Majalengka, Bandung, Sukabumi, Cianjur, Karawang, Purwakarta, dan Subang. Namun, dari sembilan kabupaten di Jawa Barat tersebut, TKI dari daerah Kabupaten Sukabumi memiliki karakteristik tersendiri. Bisa dibilang, TKI sangat lekat bagi Kabupaten Sukabumi. Jumlah penduduk Kabupaten Sukabumi sekitar 2,4 juta orang, di mana angkatan kerja sekitat 793 ribu orang namun yang bekerja hanya 739 ribu. Ada kurang lebih 300 ribu orang yang menjadi pengangguran. Dengan keterbatasan peluang kerja di dalam negeri tersebut, wajar jika penduduk Kabupaten Sukabumi banyak memilih bekerja ke luar negeri. Selain itu, para TKI dianggap sebagai pahlawan daerah, karena menyumbang dana yang tidak sedikit. Berdasarkan data PT Pos Indonesia, selama 2015 uang dari luar negeri yang dikirim ke Kabupaten Sukabumi mencapai lebih dari RP 700 miliar. Singkatnya, berdasarkan laporan PT Pos Indonesia (2015), hampir 90 persen pengirim uang luar negeri ke Indonesia di donimasi TKI asal Sukabumi.

Hal sebagaimana telah diuraikan juga dibenarkan oleh Kepala Dinas Tenaga Kerja dan Transmigrasi (Disnakertrans) Kabupaten Sukabumi, Aam Amar Halim kepada Radar Sukabumi, selasa (5/1/2015). Menurut Aam Amar Halim, "Setiap tahun, lalu lintas pengiriman uang dari luar negeri sangat tinggi. Apalagi, di akhir 2015 kemarin angka mencapai Rp 700 miliar lebih yang masuk ke Kabupaten Sukabumi. Data tersebut merupakan laporan dari pengiriman yang melalui PT Pos Indonesia." Para TKI di Sukabumi masih didominasi bekerja di Timur Tengah dan sejumlah negara ASEAN lainnya. Data sebagaimana diuraikan di atas menunjukkan bahwa sampai saat ini jumlah TKI yang bekerja di luar negeri asal Kabupaten Sukabumi sangat tinggi. Apa yang menjadi keinginan Kepala Disnakertrans Kabupaten Sukabumi tersebut sejalan dengan program BNP2TKI yang akan melatih sedikitnya 15 ribu TKI Purna agar menjadi wirausaha baru sehingga mereka tak tergiur untuk kembali bekerja di luar negeri.

Berdasarkan uraian-uraian di atas dapat disimpulkan bahwa mendesak dilakukan pelatihan berwirausaha kepada para TKI Purna di Kabupaten Sukabumi. Melalui kegiatan pelatihan manajemen usaha dan pengelolaan keuangan diharapkan menjadi bekal utama dalam membuka suatu wirausaha dan melihat suatun potensi bisnis.

\section{B. PERUMUSAN MASALAH}

Berdasarkan analisis situasi di atas, maka masalah dalam kegiatan ini dirumuskan sebagai berikut: "Bagaimanakah manajemen usaha dan 
pengelolaan keuangan UKM sebagai bentuk pembinaan usaha mandiri bagi para TKI purna?".

\section{TUJUAN KEGIATAN}

Kegiatan pengabdian Masyarakat inimemiliki tujuan sebagai berikut:

1.Untuk melatih para TKI Purna memiliki kemampuan literasi keuangan sebagai modal berwirausaha.

2.Untuk melatih para TKI Purna berwirausaha untuk membuat prosek usaha dengan menganalisis peluang potensi wilayang sebagai produk unggulan

3.Untuk melatih para TKI Purna berwirausaha untuk mampu membuat laporan keuangan usaha untuk mampu menyerap kredit sebagai modal usaha.

\section{MANFAAT KEGIATAN}

Adapun manfaat pengabdian masyarakat yaitu :

1. Para TKI Purna memiliki kemampuan literasi keuangan sebagai bekal mereka berwirausaha.

2. Para TKI Purna mampu membuka usaha sesuai bidang yang diminati dan potensi yang dimiliki.

3. Para TKI Purna mampu menjadi pelaku sekaligus membuka usaha yang mempunyai prospek bagus

4. Terbinanya hubungan yang baik antara para TKI Purna dan Stakeholder di Kabupaten Sukabumi Jawa Barat dengan Universitas Negeri Jakarta.

\section{KAJIAN PUSTAKA}

\section{A. TENAGA KERJA INDONESIA PURNA}

Tenaga Kerja Indonesia (TKI) adalah sebutan bagi warga negara Indonesia yang bekerja di luar negeri (seperti Malaysia, Timur Tengah, Hongkong, Taiwan, Korea, Australia dan Amerika Serikat) dalam hubungan kerja untuk jangka waktu tertentu dengan menerima upah. Selanjutnya pelaksana penempatan TKI di Luar Negeri ini dikelola oleh Pemerintah dan Pelaksanaan penempatan TKI yang diatur oleh Perusahaan Pengerah Jasa Ketenagakerjaan Indonesia (singkat PJTKI) yang telah disetujui dan tetap berada dibawah pengawasan Pemerintah, karena sesuai Pasal 4 UU 39/2004, yang berbunyi "Orang perseorangan dilarang menempatkan warga negara Indonesia untuk bekerja di luar negeri."

Adapun yang dimaksud dengan TKI Purna adalah TKI yang telah habis kontrak kerjanya dan telah kembali ke Indonesia, serta kembali ke daerah asal. Terkait TKI Purna ini, Nusron Wahid (2015) memberikan batasan bahwa TKI Purna ini TKI yang telah menyelesaikan kontrak kerja minimal selama dua tahun dan tinggal di Indonesia kurang dari satu tahun.

Menurut Kepala Dinas Tenaga Kerja dan Transmigrasi (Disnakertrans) Kabupaten Sukabumi, Aam Amar Halim (2015), jumlah TKI Purna yang berhasil didata sejumlah 400 orang. Sebagian dari TKI Purna inilah yang akan dilatih berwirausaha baik di bidang keuangan, jasa, maupun ekonomi kreatif. Para TKI Purna di Sukabumi ini diharapkan tidak lagi berkeinginan untuk kembali ke luar negeri, tetapi memilih menggeluti usaha di daerahnya pasca mendapat pelatihan berwirausaha.

\section{B. WIRAUSAHA, KEWIRAUSAHAAN DAN EKONOMI KREATIF}

Wirausaha dapat disebut sebagai pahlawan ekonomi. Mengapa? Karena meski jumlahnya kecil, kontribusi mereka tidak kurang dari $70 \%$ terhadap perekonomian nasional. Wirausaha bergerak diberbagai sektor usaha termasuk Usaha Mikro, Kecil dan Menengah (UMKM). Data Statistik Badan Pusat Statistika (BPS, 2015) menunjukkan bahwa jumlah UMKM di Indonesia sebanyak 57,9 juta. Sektor ini berkontribusi terhadap PDB lebih kurang setara 59\%. Selain itu, sektor ini mampu menyerap tenaga kerja sebesar 97,30\%. Data tersebut menunjukkan bahwa sektor ini ternyata mampu mengurangi angka pengangguran.

Ekonom manapun akan sepakat jika kewirausahaan itu menjadi salah satu karakter yang penting dimiliki anak didik. Karakter kewirausahaan, memiliki kontribusi yang cukup besar bagi kehidupan anak didik di masa yang akan datang. Data penelitian yang dilakukan di Harvard University Amerika Serikat, diketahui bahwa ternyata kesuksesan seseorang tidak ditentukan semata-mata oleh pengetahuan dan 
kemampuan teknis (hard skill) saja, tetapi lebih oleh kemampuan mengelola diri dan orang lain (soft skills). Penelitian ini mengungkapkan, kesuksesan hanya ditentukan sekitar $20 \%$ oleh hard skill dan sisanya $80 \%$ oleh soft skills. Bahkan, orang-orang tersukses di dunia bisa berhasil dikarenakan lebih banyak didukung kemampuan soft skills dari pada hard skill. Singkatnya, tingkat kecerdasan hanya menyumbang sekitar 20-30 persen, sementara karakter kewirausahaan yang didukung kecerdasan sosial justru menyumbang 80 persen keberhasilan seseorang kelak di kemudian hari.

Sayangnya, jumlah wirausaha saat ini tergolong minim. Bahkan hanya kisaran 1,65\% dari total penduduk Indonesia. Padahal, sebuah negara akan menikmati kemajuan ekonomi bila ditopang kuantitas wirausahanya paling tidak 2,5\%. Jumlah wirausahawan di Indonesia ini tentu jauh lebih rendah bila dibandingkan dengan negara-negara tetangga, seperti Malaysia, Thailand dan Singapora. Pertanyaan yang muncul kemudian, apa yang dimaksud dengan kewirausahaan/entrepreneurship dan pendidikan kewirausahaan itu?

Entrepreneurship adalah sebuah karakter kombinatif yang merupakan fusi antara sikap kompetitif, visioner, kejujuran, pelayanan, pemberdayaan, pantang menyerah, dan kemandirian. Karakter ini bersatu dan menjadi kebutuhan langsung dalam proses wirausaha. Secara sederhana, entrepreneurship memiliki ciri-ciri swadaya usaha serta mengandung komponen manajemen pemasaran, produksi, dan finansial. Seorang entrepreneur/wirausahawan yang memiliki potensi sukses adalah mereka yang mengerti kegunaan pendidikan untuk menunjang kegiatan serta mau belajar untuk meningkatkan pengetahuan. Lingkungan pendidikan dimanfaatkan oleh entrepreneur sebagai sarana mencapai tujuan. Adapun pendidikan di sini berarti pemahaman suatu masalah yang dilihat dari sudut keilmuan atau teori sebagai landasan berpikir.

Menurut Pinchot (Husaini Usman, 2010), karakter kewirausahaan itu merupakan kemampuan untuk menginternalisasikan bakat, rekayasa, dan peluang yang ada. Sementara, wirausaha adalah orang yang berani mengambil resiko, inovatif, kreatif, pantang menyerah, dan mampu menyia- sati peluang secara tepat. Lebih dari itu, karakter kewirausahaan juga sangat urgen dalam menentukan kemajuan perekonomian suatu negara. Bukan hanya ketepatan prediksi dan analisis yang tepat, tetapi juga merangsang terjadinya invensi dan inovasi penemuan-penemuan baru yang lebih efektif bagi pertumbuhan ekonomi.

Menurut Kemendiknas (2010:15-17), kewirausahan adalah suatu sikap, jiwa dan kemampuan untuk menciptakan sesuatu yang baru, yang sangat bernilai dan berguna; baik bagi dirinya sendiri maupun bagi orang lain. Kewirausahaan ini merupakan sikap mental dan jiwa, yang selalu aktif atau kreatif, berdaya, bercipta, berkarya, bersahaja, dan berusaha dalam rangka meningkatkan pendapatan atas kegiatan usahanya. Sementara wirausaha adalah orang yang terampil memanfaatkan peluang dalam mengembangkan usahanya, dengan tujuan untuk meningkatkan kehidupannya.

Menurut Norman M. Scarborough (Kemendiknas, 2010), wirausahawan adalah orang yang memiliki kemampuan melihat dan menilai kesempatan-kesempatan bisnis, mengumpulkan pelbagai sumber daya yang dibutuhkan, untuk mengambil keuntungan dan tindakan yang tepat, serta memiliki sifat, watak dan kemauan untuk mewujudkan gagasan inovatif rangka meraih sukses/meningkatkan pendapatan. Inti dari pendapat Norman M. Scarborough dan Thomas W. Zimmerer ini adalah bahwa wirausaha merupakan orang yang memiliki karakter wirausaha, dan mengaplikasikan hakikat kewirausahaan itu dalam hidupnya. Dengan kata lain, wirausaha adalah orang yang memiliki jiwa kreativitas, dan inovatif yang tinggi dalam hidupnya.

Adapun ekonomi kreatif adalah istilah baru yang untuk pertamakali diperkenalkan oleh ekonom John Howkins dalam bukunya The Creative Economy: How People Make Money from Ideas (2001). Tak dinyana, gagasan itu mampu menginspirasi dan mendorong lahirnya aliran baru dalam ekonomi modern. Ekonomi kreatif merupakan konsep yang mengintensifkan informasi dan kreativitas dengan mengandalkan ide dan pengetahuan dari sumberdaya manusia sebagai faktor produksi yang utama. Konsep ini akan efektif jika didukung dengan keberadaan industri kreatif yang menjadi pengejawantahannya. 
Sektor ekonomi kreatif dianggap paling menjanjikan dewasa ini. Data yang dirilis PBB setahun lalu menyebutkan bahwa ekonomi kreatif berada pada sektor paling dinamis dalam perekonomian dunia dan menawarkan kesempatan pertumbuhan yang tinggi di negaranegara berkembang. Lebih dari itu, sektor ekonomi kreatif dapat berkontribusi besar pada pertumbuhan ekonomi dan kemakmuran, terutama bagi negara-negara berkembang. Sekitar 30 negara telah meraup keuntungan dari ekonomi kreatif dan lebih dari 100 negara telah memberikan perhatian serius dengan menggunakan aset warisan budaya mereka sebagai modal dalam perekonomian.

Sementara menurut data yang dirilis UNCTAD (dalam Somasir, 2015), diketahui nilai ekonomi kreatif dunia lebih dari 375,84 miliar dollar AS pada 2002 dan meningkat cukup signifikan menjadi 842, 2 miliar dollar AS pada 2011 dengan pertumbuhan 7,35 persen per tahun pada 2003-2011. Berdasarkan data tersebut Howkins (2011) bahkan mengestimasi nilai ekonomi kreatif dunia mencapai 2,2 triliun dollar AS pada 2020 dengan pertumbuhan 5 persen per tahun.

Di Indonesia, sektor ekonomi kreatif diyakini menjadi alternatif pengentasan pengurangan. Seperti kita ketahui, angka pengangguran di Indonesia setiap tahun semakin meningkat. Data Badan Pusat Statistik (BPS, 2014) menyebut sebanyak 9,5 persen atau 688,660 orang dari total pengangguran secara umum merupakan kalangan terdidik. Sebagian besar mereka bahkan merupakan lulusan terbaik dari berbagai perguruan tinggi bergengsi negeri ini.

Sejak tahun 2011 hingga 2013 ekonomi kreatif sudah menyumbang 7 persen dengan total nilai $\mathrm{Rp}$ 641,8 triliun (2014) dan pertumbuhan 5,74 persen pada 2013. Jumlah tenaga kerja yang terserap dari sektor ekonomi kreatif ini lebih dari 11,5 juta orang dengan pertumbuhan ratarata sepanjang tahun 2013 sebesar 1,1 persen. Mengarusutamakan sektor ekonomi kreatif juga tidak terlalu berat di negeri ini. Pasalnya, modal ekonomi kreatif melimpah-ruah. Seperti keanekaragaman budaya, suku bangsa, jumlah penduduk yang memadai, lokasi geografis yang sangat strategis, hamparan laut tropis yang amat kaya dengan sumberdaya alam, dan sebagainya. Dengan modal melimpah itu, sebenarnya ekonomi kreatif di Indonesia tidak akan pernah habis atau berkurang. Setiap wilayah di negeri ini bahkan dapat berkembang tanpa mengorbankan sumberdaya alam sedikitpun.

Andai saja ekonomi kreatif ini dapat efektif di setiap wilayah, maka tidak akan terjadi proses urbanisasi-karena motif utama kegiatan urbanisasi adalah pemenuhan kebutuhan ekonomi. Penduduk di setiap wilayah, melalui ekonomi kreatif, tidak perlu berbondongbondong pergi ke kota untuk mencari pekerjaan. Mereka dapat menjual hasil kreativitasnya melalui dunia online/daring-yang terkoneksi hampir di berbagai penjuru dunia.

\section{MANAJEMEN USAHA}

Untuk menjalankan manajemen usaha diperlukan beberapa tahapan, yaitu:

\section{Identifikasi Peluang Bisnis}

Perencanaan usaha sangat penting bagi para wirausahawan baru. Hal tersebut akan menentukan persiapan yang matang untuk terjun secara totalitas dalam menggeluti dunia bisnis dengan resikonya. Setelah perencanaan usaha selesai dibuat, calon pengusaha harus melakukan studi kelayakan bisnis untuk menilai apakah bisnis tersebut layak dilaksanakan dilihat dari beberapa perspektif. Studi kelayakan usaha yang dipersiapkan terdiri dari:

\section{- Studi Manajemen.}

Seluruh sumberdaya manusia yang terlibat dalam bisnis/usaha yang dijalankan harus dipersiapkan dengan baik. Banyak usaha gagal karena kita tidak dapat mengelola usaha melalui orang lain yang kita kontrol.

Bagaimana dengan karyawan, siapa yang mengelola usaha tersebut, serta bagaimana kemampuan masing-masing SDM dalam mengelola unit usaha yang dijalankan. Dalam pemeilihan SDM juga perlu pertimbangan selain kapasitas perorangan, juga apakah masing-masing jenis pekerjaan disesuaikan dengan kompetensi ilmu setiap karyawan atau semua bidang ilmu dapat melaksanakan jenis pekerjaan yang 
dibebankan. Tentu saja semakin tinggi tingkat pendidikan karyawan juga mensyaratkan gaji/upah yang tinggi pula.

\section{- Studi Pasar.}

Studi pasar meliputi studi mengenai konsumen. Apakah konsumen yang menjadi pasar sasaran produk/jasa yang akan dijalankan masih terbuka luas dan cukup banyak, apakah pasar sasaran produk/ jasa yang akan dijalankan hanya melayani segmen tertentu saja, atau bahkan melayani semua segmen.

\section{- Studi Modal.}

Studi mengenai modal meliputi dari mana sumberdana usaha berasal. Apakah $100 \%$ modal pemilik, apakah hutang (bank, pihak lain), ataukah kerjasama dengan pihak lain. Demikian pula dengan besarnya modal yang digunakan untuk membuka usaha, apakah diperlukan modal yang sangat besar, sedang, ataukah cukup denganmodal kecil. Setelahmengatahui seberapa besar modal yang diperlukan, baru ditentukan apakah modal tersebut cukup didanai dari modal pemilik saja ataukah perlu meminjam dari pihak lain.

- Studi Persaingan.

Studi mengenai persaingan meliputi analisis competitor yang juga bermain di lahan yang sama.

Berikut ini merupakan bentuk formal dari business plan:

1) Halaman Depan.

Dalam halaman depan perlu dicantumkan nama dan alamat perusahaan, nama orang yang bertanggung jawab serta alamat yang bisa dihubungi sewaktu-waktu. Hal ini sangat penting karena menunjukkan bahwa bisnis atau perusahaan yang dijalankan tidak fiktif dan dapat ditunjukkan pertanggungjawabannya.

2) Daftar Isi.

Membuat daftar isi business plan secara rinci dengan disertai nomor halaman.

3) Rangkuman eksekutif.

Rangkuman eksekutif ini sangat penting karena pembaca ingin melihat secara cepat mengenai isi keseluruhan dari business plan yang telah dibuat. Rangkuman ini merupakan inti dari semua perencanaan.

4) Penjelasan tentang Perusahaan.

Penjelasan ini berisi strategi perusahaan serta tim manajemen yang mengelola perusahaan.

5) Pemasaran

Dalam rencana pemasaran dijelaskan pasar mana yang dituju, seberapa besar potensi pasar dan berbagai strategi serta ramalan tentang target konsumen dimasa yang akan datang

6) Barang dan jasa yang dihasilkan.

Dijelaskan mengenai kualitas, kuantitas dan kegunaan dan keistimewaan barang dan jasa yang ditawarkan

7) Usaha meningkatkan penjualan.

Berisi penjelasan tentang berbagai teknik promosi yang akan digunakan, tenaga penjualan, perwakilan-perwakilan penjualan, dsb

8) Permodalan.

Dalam rencana permodalan akan dijelaskan gambaran menegenai proyek permodalan neraca, aliran kas, dan proyeksi pendapatan

9) Kelengkapan dokumen tambahan yang dibutuhkan dalam usaha.

Dilampirkan berbagai keterangan yang diperlukan untuk melengkapi business plan. Misalnya akte pendirian perusahaan, SIUPP, sertifikat, dsb

\section{LAPORAN KEUANGAN}

Banyak usaha kecil yang melakukan usaha tanpa adanya pencatatan secara khusus serta mencampurkan Antara pendapatan usaha dengan keluarga. Hal tersebut akan sulit membuat usaha berkembang dan mampu memenuhi standar permintaan konsumen. Pelayanan yang baik juga akan sulit dilaksanakan karena bercampurnya usaha dengan kegiatan rumah tangga. Pada sisi lain apabila usahanya berkembang akan sulit memperoleh bantuan melalui kredit yang tersedia oleh lembaga bank maupun non bank.

Laporan keuangan merupakan alat yang digunakan untuk mengkomunikasikan informasi keuangan dari suatu perusahaan kepada pihakpihak yang berkepentingan sehingga dapat dijadi- 
kan suatu acuan dalam pengambilan keputusan. Tujuan laporan keuangan berdasarkan Standar Akuntansi Keuangan (SAK) adalah menyediakan informasi yang menyangkut posisi keuangan, kinerja serta perubahan posisi keuangan suatu perusahaan yang bermanfaat bagi sejumlah besar pemakai dalam pengambilan keputusan ekonomi. Beberapa jenis laporan keuangan yang sering digunakan: 1) Neraca, 2) Laporan rugi laba, 3) Laporan arus kas.

\section{METODE PELAKSANAAN}

\section{A. METODE PELAKSANAAN}

Metode pelaksanaan kegiatan ini adalah berupa pelatihan dan workshop, di mana para peserta belajar teori dan mempraktekan langsung bagaimana membuat prospek dan manajemen usaha serta membuat laporan keuangan UKM.

\section{B. KERANGKA PEMECAHAN MASALAH}

Salah satu upaya yang dapat dilaksanakan dalam rangka pemecahan masalah manajemen usaha dan pengelolaan keuangan UKM bagi para TKI purna berdasarkan hasil survey awal, yaitu melalui pelatihan bagi para TKI purna, dilakukan dengan tahapan sebagai berikut :

1. Mengadakan koordinasi dengan pihak terkait yaitu pihak LPM dan Lembaga Masyarakat setempat/kelurahan untuk perizinan

2. Menyusun jadwal kegiatan pelatihan bagi para TKI purna

3. Menggandakan materi power point untuk peserta pelatihan

4. Melaksanakan program "pelatihan manajemen keuangan dan manajemen usaha bagi para TKI purna di Sukabumi, Jawa Barat"

5. Melakukan evaluasi program dan penyusunan laporan

\section{KHALAYAK SASARAN}

Sasaran peserta pelaksanaan kegiatan pelatihan berwirausaha manajemen usaha dan pembuatan laporan keuangan bagi Tenaga Kerja Indonesia Purna ini adalah TKI Purna di wilayah Sukabumi, Jawabarat yang telah kembali ke tanah air dari Timur Tengah, Malaysia, dan Singapura.

\section{TEMPAT DAN WAKTU KEGIATAN}

Kegiatan pelatihan ini dilaksanakan di Kantor Kelurahan Desa Cibolang Kelurahan Gunung Guruh, pada tanggal 20 Agustus 2016, pukul 08.00 - 13.00 WIB sampai selesai.

\section{PELAKSANAAN KEGIATAN}

A. REALISASI PEMECAHAN MASALAH

Berdasarkan masalah sebagaimana yang diuraikan di atas, maka langkah pemecahan masalah dilaksanakan sebagai berikut :

1. Mengadakan koordinasi dengan pihakpihak terkait:

a. Mengurus surat perizinan Kampus dari LPM dan Universitas

b. Mengurus perizinan tempat dengan Kelurahan dan Tokoh masyarakat setempat (RT/RW)

c. Narasumber pelatihan dalam manajemen usaha dan pengelolaan keuangan UKM bagi para TKI purna.

2. Menyusun agenda atau susunan acara dan pelaksanaan kegiatan

\section{B. SASARAN}

Sasaran peserta pelaksanaan kegiatan pelatihan berwirausaha manajemen usaha dan pembuatan laporan keuangan bagi Tenaga Kerja Indonesia Purna ini adalah 22 orang warga desa di Desa Cibolang, Sukabumi - Jawa Barat yang merupakan TKI Purna.

\section{KETERKAITAN}

Program pelatihan ini bersifat terpadu, maka banyak pihak yang terkait dalam kegiatan ini yaitu: Kelurahan, RT dan RW, Tokoh Masyarakat, dan Para TKI Purna.

\section{METODE}

Untuk mensukseskan program pelatihan ini, metode yang digunakan adalah praktek dan partisipasi aktif dengan melalui tahapan: (1) pemberian informasi dengan power point dan print out yang dibagikan. Metode ini penting untuk menyampaikan informasi-informasi penting berkaitan dengan laporan keuangan dan akses usaha kecil, (2) tanya jawab yang dilaksanakan secara aktif oleh seluruh peserta, (3) praktek simulasi pembuatan laporan keuangan sederhana, 
(4) Motivasi membangun usaha mandiri berdasarkan potensi wilayah

\section{HASIL KEGIATAN}

\section{A. HASIL KEGIATAN}

Hasil kegiatan dari pelatihan manajemen usaha dan pengelolaan keuangan UKM bagi para TKI purna, diantaranya :

1. Para peserta kegiatan pelatihan/TKI purna mampu membuat manajemen usaha yang saat ini sedang dikembangkannya sehingga mempunyai nilai lebih dalam daya saing, serta membuat mitra usaha dengan lembaga maupun pengusaha lainnya.

2. Terjadinya sikap positif dalam menghadapi peluang usaha dan kondisi ekonomi yang mendorong mentalitas usaha yang kuat untuk membangun bisnis di negeri sendiri.

3. Meningkatkan kemampuan dalam mengelola keuangan dengan akses lembaga keuangan pemberi modal, serta memisahkan pengelolaan keuangan usaha dan pribadi.

4. Memiliki pengetahuan syarat serta proses dalam pembuatan standar laporan keuangan UKM dalam akses kredit modal dari lembaga Bank/Non Bank.

\section{B. HASIL EVALUASI}

Hasil evaluasi dilakukan terhadap proses pelatihan bagi TKI purna di Sukabumi, Jawa Barat. Selama ini para pahlawan devisa belum diberikan akses pembinaan usaha dan keuangan yang cukup oleh pemerintah sehingga program serupa dan keberlanjutannya sangat bermanfaat bagi mereka.

\section{KESIMPULAN}

Setelah dilakukan kegiatan Pengabdian pada Masyarakat ini, melalui pelatihan manajemen usaha dan pengelolaan keuangan bagi para TKI purna maka dapat disimpulkan bahwa: Pelatihan manajemen usaha dan pengelolaan keuangan bagi TKI purna merupakan sarana yang efektif untuk memberikan informasi, memotivasi, sekaligus mempraktekan/melatih mereka memanfaatkan peluang usaha, mengelola usaha secara mandiri, mengelola keuangan dengan baik serta mengakses permodalan dari lembaga keuangan. Disamping itu tanggung jawab Perguruan Tinggi dalam Tri Dharma Perguruan Tinggi dapat terealisasi dengan baik.

\section{DAFTAR PUSTAKA}

Agus Wibowo. (2011). Pendidikan kewirausahaan: konsep dan strategi implementasi. Yogyakarta: Pustaka Pelajar.

(2015). "Investasi Pendidikan dan Bonus Demografi." Media Indonesia, Edisi Senin, 18 Mei. . (2015). "Ekonomi Kreatif Entaskan Pengangguran.” Koran Jakarta, Edisi Rabu, 4 Maret.

Dedi Purwana E.S. (2011). Menjadi Wirausaha Sukses. Bandung: Rosda Karya

Husaini Usman. (2006). Manajemen, teori, praktek dan riset pendidikan. Jakarta: Bumi Aksara.

Kementrian Pendidikan Nasional. (2010). Pengembangan Pendidikan Budaya dan Karakter Bangsa. Bahan Pelatihan Penguatan Metodologi Pembelajaran Berdasarkan Nilai-nilai Budaya Untuk Membentuk Daya Saing dan Karakter Bangsa. Jakarta: Kementrian Pendidikan Nasional. .(2010). Buku Induk Pembangunan Karakter. Jakarta : Kementrian Pendidikan Nasional.

(2011). Pedoman Pelaksanaan Pendidikan Karakter (Bedasarkan Pengalaman di Satuan Pendidikan Rintisan). Jakarta : Kementrian Pendidikan Nasional Badan Penelitian dan Pengembangan Pusat Kurikulum dan Perbukuan.

Nusron Wahid. (2015). BNP2TKI: TKI Purna Kini Lebih Mudah Kembali Bekerja di Luar Negeri.http://bisniskeuangan.kompas. com/read/2015/11/30/164300526/BNP2TKI. TKI.Purna.Kini.Lebih.Mudah.Kembali.Bekerja. di.Luar.Negeri

Thomas W. Zimmereer and Norman M. Scarboroug (2006), Essential of entrepreneurship and small business management, fourth edition. Pearson Prentice- Hall Inc. 
Sembilan daerah di Jabar jadi pemasok TKI terbanyak. Diakses tanggal 19 Februari 2016, Jam 07.15 WIB pada laman: http://nasional. republika.co.id/berita/nasional/pemprov-jabar/ 16/02/16/o2mvai365-sembilan-daerah-di-jabarjadi-pemasok-terbanyak-tki.

Penempatan TKI di Luar Negeri. Diakses tanggal 20 Februari 2016, Jam 09.15 WIB pada laman: http://www.bnp2tki.go.id/readfull/9801/ Sepanjang-2014-BNP2TKI-MencatatPenempatan-TKI-429.872-Orang.

Cegah TKI Bermasalah Di Sukabumi. Diakses tanggal 20 Februari 2016, Jam 09.15 WIB pada laman: http://www.beritasatu.com/ nasional/299359-cegah-tki-bermasalah-bnp2tkisosialisasi-di-kabupaten-sukabumi.html.

BNP2TKI Akan Latih 15.000 TKI Purna Jadi Wirausaha Baru. Diakses tanggal 21 Februari 2016, Jam 12.15 WIB pada laman: http://www. bnp2tki.go.id/read/9982/BNP2TKI-Akan-Latih-
15.000-TKI-Purna-Jadi-Wirausaha-Baru.

Kiriman TKI Selama 2015, Rp 700 M Mengalir ke Kabupaten Sukabumi. Diakses tanggal 19 Februari 2016, Jam 12.15 WIB pada laman: http://jabar.pojoksatu.id/sukabumi/ 2016/01/06/kiriman-tki-selama-2015-rp-700-mmengalir-ke-kabupaten/.

TKI Asal Sukabumi Berpendidikan Rendah. Diakses tanggal 19 Februari 2016, Jam 12.15 WIB padalaman:http:/www.pikiran-rakyat.com/jawabarat/2015/05/29/329100/tki-asal-sukabumiberpendidikan-rendah.

Cegah TKI Bermasalah, BNP2TKI Sosialisasi di Kabupaten Sukabumi. Diakses tanggal 19 Februari 2016, Jam 12.15 WIB pada laman: http://www.bnp2tki.go.id/read/10414/ Cegah-TKI-Bermasalah-BNP2TKI-Sosialisasidi Kabupaten-Sukabumi.html 